\title{
KUALITAS PELAYANAN : REALIBILITY, RESPONSIVENESS DENGAN KEPUASAN PASIEN DI LOKET PENDAFTARAN RSUD KABUPATEN KEPAHIANG
}

\author{
Novega \\ Program Studi Ilmu Kesehatan Masyarakat Bhakti Husada Bengkulu \\ Email:zj.novega@gmail.com
}

\begin{abstract}
ABSTRAK
Kualitas pelayanan merupakan salah satu faktor penting dalam pemanfaatan layanan kesehatan. Penilaian terhadap kualitas pelayanan yang baik tidak terbatas pada kesembuhan penyakit secara fisik, tetapi juga terhadap sikap, pengetahuan dan ketrampilan petugas dalam memberikan pelayanan, komunikasi, informasi, sopan santun, tepat waktu, tanggap dan tersedianya sarana serta lingkungan fisik yang memadai. Kepuasan pasien adalah "a persons feeling of pelasure or disappointment resulting from comparing a product's received performance (or outcome) in relations to the person's expectation" perasaan senang atau kecewa seseorang yang berasal dari perbandingan antara persepsi atau produk yang dirasakan dan diharapkan oleh pasien. Penelitian ini menggunakan pendekatan uji hubungan antar variabel dengan pendekatan kuantitatif. pengambilan sampel dengan metode Simple Random Sampling, Sampel penelitian adalah pasien yang menggunakan jasa Rumah Sakit terdiri dari pasien rawat jalan sebanyak 98 orang, dengan menggunakan metode cross sectional, dan analisis data dilakukan dengan menggunakan Chi Square. Realibility $(59,2 \%)$, responsiveness $(58,2 \%)$, dan analisis Chi-Square diperoleh nilai $\boldsymbol{\rho}=0,034<0.05$. Berdasarkan uji statistik dan pembahasan diketahui bahwa ada hubungan realibility, responsiveness dengan kepuasaan pasien di loket pendaftran RSUD Kabupaten Kepahiang.

Kata Kunci : Realibility, Responsiveness, Kepuasaan Pasien.
\end{abstract}

\section{ABSTRACT}

Quality of service is one of the important factors in the utilization of health services. Assessment of good service quality is not limited to physical healing of disease, but also on attitudes, knowledge and skills of officers in providing services, communication, information, courtesy, timely, responsive and the availability of adequate physical facilities and environment. Patient satisfaction is a persons feeling of pelasure or disappointment resulting from comparing a product's received performance (or outcome) in relations to the person's expectation" feeling happy or disappointed someone that comes from a comparison between the perceptions or products felt and expected by the patient. This study was the approach to test the relationship between variables with a quantitative approach. The sampling method was Simple Random Sampling, the research sample was patients who used hospital services consisting of 98 patients, using the cross sectional method, and data analysis was performed using Chi Square. The result : Realibility (59,2\%), responsiveness (58,2\%), Chi-Square Analysis : $\boldsymbol{\rho}=$ $0,034<0.05$. Based on statistical tests and discussion, it is known that there is a relationship between reliability, responsiveness and patient satisfaction at the registration counter of the RSUD Kepahiang District.

Keyword : Realibility, Responsiveness, Customer satisfication 
Rumah sakit adalah suatu organisasi yang dilakukan oleh tenaga medis profesional yang terorganisir baik dari sarana prasarana kedokteran yang permanen, pelayanan kedokteran, asuhan keperawatan yang berkesinambungan, diagnosis serta pengobatan penyakit yang diderita oleh pasien.

Rumah sakit mempunyai berbagai macam jenis pelayanan kesehatan yang dapat diunggulkan untuk mempertahankan loyalitas pasien. Salah satu jenis pelayanan kesehatan yang ada di rumah sakit yaitu pelayanan rawat jalan. pelayanan rawat jalan dewasa ini menjadi perhatian utama manajemen rumah sakit, karena jumlah pasien rawat jalan yang lebih banyak dibandingkan dengan perawatan yang lain. pelayanan rawat jalan menjadi pangsa pasar yang menjanjikan dan dapat mendatangkan keuntungan financial bagi rumah sakit. Persaingan yang semakin ketat akhirakhir ini menuntut sebuah lembaga penyedia jasa untuk selalu memanjakan pelanggan dengan memberikan pelayanan terbaik. Para pelanggan mencari produk berupa barang

atau jasa dari perusahaan yang dapat memberikan pelayanan yang terbaik kepadanya.

Kabupaten Kepahiang terdapat Rumah Sakit berstatus tipe $\mathrm{C}$ diberi nama RSUD Kabupaten Kepahiang yang pengelolahan rumah sakit diserahkan kepada Pemerintah Kabupaten Kepahiang. Bersadarkan surat keputusan Menteri Kesehatan Republik Indonesia Nomor : HK.02.03/I/0198/2013 Pada tanggal 29 Januari 2013 tentang Penetapan Kelas RSUD Kabupaten Kepahiang Provinsi Bengkulu ditetapkan menjadi RS Kelas C.

Dalam pola interaksi sosial, persepsi pasien sangat berperan dalam menggambarkan tingkat kepuasaan pasien terhadap pelayanan rumah sakit. Berdasarkan persepsi ini akan timbul kesan pasien terhadap rumah sakit, yang selanjutnya dapat disebut sebagai kualitas pelayanan rumah sakit. Kesan yang didapat dibangun atas persepsi masing-masing individu yang berelasi.

Data yang di peroleh di RSUD Kabupaten Kepahiang selama tahun 2019 jumlah pasien rawat jalan dari 7 (Tujuh) poli terdiri dari : Poli Umum, Poli Kebidanan,
Poli Syaraf, Poli Bedah, Poli Gigi, Poli Anak, Poli Dalam adalah 5.300 Orang. Artinya rata-rata 1 bulan kunjungan pasien ditahun 2019 adalah 480 orang.

Menurut peneliti yang telah melakukan pengamatan sebelum melakukan penelitian mendapati pelayanan kesehatan di Loket Pendaftaran RSUD Kepahiang, masih perlu ditingkatkan terutama dalam hal manejemen waktu dan adminstrasi rumah sakit. Pelayanan terhadap pasien dilakukan tidak tepat waktu, sehingga pasien menunggu berjam-jam untuk mendapatkan pelayanan. Selain itu, prosedur administrasi yang berbelitbelit menyebabkan pasien sebagai konsumen sulit untuk mendapatkan palayanan kesehatan. Petugas loket pendaftaran seperti kurang handal dan tidak tanggap dalam melayani pasien. Berdasarkan survei awal yang dilakukan peneliti terhadap 10 pasien rawat jalan yang sedang menunggu, 7 pasien mengeluh tidak puas sewaktu di loket pendaftaran, lamanya waktu tunggu, petugas kurang handal dan tidak tanggap terhadap banyaknya pasien yang mendaftar. Sementara petugas yang ada jumlahnya banyak.

Dalam menganalis permasalahan tersebut diatas, maka peneliti mencoba melihat dari sisi penerima pelayanan atau pelanggan dalam mengevaluasi kesenjangan antara harapan dan persepsi terhadap kualitas jasa pelayanan kesehatan yang diberikan oleh instalasi rawat jalan RSUD Kabupaten Kepahiang. Kesenjangan merupakan ketidaksesuaian antara pelayanan yang dipersepsikan (perceived service) dan pelayanan yang diharapkan (expected service).

\section{Metode Penelitian}

Penelitian ini bersifat deskriptif analitik dengan desain penelitian Cross Sectional dimana dalam desain penelitian ini, variabel independen (Reliability dan Responsiveness) dan variabel dependen (Kepuasan) diukur 
dalam waktu bersamaan dengan cara pendekatan, observasi atau pengumpulan data sekaligus pada suatu saat (Point Time Approach) artinya, tiap subyek hanya diobservasi sekali saja dan pengukurannya dilakukan terhadap status karakter atau variabel subyek pada saat pemeriksaan.

\section{Hasil dan Pembahasan}

\section{Analisis Univariat}

Analisis ini dilakukan untuk mendapatkan gambaran distribusi

\section{1) Kepuasan Pasien}

frekuensi variabel yang diteliti berdasarkan subjek penelitian

Distribusi Frekuensi Responden Berdasarkan Tingkat Kepuasan Terhadap Pelayanan Petugas Loket Pendaftaran RSUD Kepahiang

\begin{tabular}{clcc}
\hline \multirow{2}{*}{ No } & $\begin{array}{c}\text { Tingkat } \\
\text { Kepuasan }\end{array}$ & $\begin{array}{c}\text { Frekuensi } \\
(\mathbf{N})\end{array}$ & $\begin{array}{c}\text { Persentase } \\
(\mathbf{\%})\end{array}$ \\
\hline 1 & Puas & 45 & 45,9 \\
2 & Tidak Puas & 53 & 54,1 \\
& Total & $\mathbf{9 8}$ & $\mathbf{1 0 0}$ \\
\hline
\end{tabular}

Tabel diatas menunjukkan bahwa dari 98 orang responden sebagian besar responden yaitu 53 orang $(54,1 \%)$ menyatakan tidak puas.

2) Kehandalan (Realibility)

Tabel 2

Distribusi Frekuensi Responden Berdasarkan Kehandalan Petugas Loket Pendaftaran RSUD Kepahiang

\begin{tabular}{clcc}
\hline No & Kehandalan & $\begin{array}{c}\text { Frekuensi } \\
(\mathbf{N})\end{array}$ & $\begin{array}{c}\text { Persentase } \\
(\mathbf{\%})\end{array}$ \\
\hline 1 & Handal & 40 & 40,8 \\
2 & Kurang Handal & 58 & 59,2 \\
& Total & $\mathbf{9 8}$ & $\mathbf{1 0 0}$ \\
\hline
\end{tabular}

Tabel diatas menunjukkan bahwa sebagian besar responden yaitu $(59,2 \%)$ menyatakanpetugas loket pendaftaran RSUD Kepahiang kurang handal.

3) Daya Tanggap (Responsiveness)

Tabel 3

Distribusi Frekuensi Responden Berdasarkan Daya Tanggap Petugas Loket Pendaftaran RSUD Kepahiang

\begin{tabular}{clcc}
\hline \multirow{2}{*}{ No } & \multicolumn{1}{c}{$\begin{array}{c}\text { Daya } \\
\text { Tanggap }\end{array}$} & $\begin{array}{c}\text { Frekuensi } \\
(\mathbf{N})\end{array}$ & $\begin{array}{c}\text { Persentase } \\
(\%)\end{array}$ \\
\hline 1 & Baik & 41 & 41,8 \\
2 & Kurang & 57 & 58,2 \\
& $\begin{array}{l}\text { Baik } \\
\text { Total }\end{array}$ & $\mathbf{9 8}$ & $\mathbf{1 0 0}$ \\
\hline
\end{tabular}


Tabel diatas menunjukkan bahwa sebagian besar responden yaitu $(58,2 \%)$ menyatakan daya tanggap petugas loket pendaftaranRSUD Kepahiangkurang baik.

\section{Analisis Bivariat}

Analisis bivariat dilakukan untuk mengetahui hubungan antara kehandalan dan daya tanggap petugas loket pendaftaran dengan kepuasan pasien rawat jalan RSUD Kepahiang. Dengan analisis ChiSquare yang diolah menggunakan sistem komputerisasi. Dengan hasil sebagai berikut :

\section{1) Hubungan kehandalan petugas loket pendaftaran dengan Kepuasan pasien rawat jalan RSUD Kepahiang}

Tabel 4

Hubungan kehandalan petugas loket pendaftaran dengan Kepuasan pasien rawat jalan RSUD Kepahiang

\begin{tabular}{|c|c|c|c|c|c|c|c|c|}
\hline \multirow{3}{*}{ Kehandalan } & \multicolumn{4}{|c|}{ Tingkat Kepuasan } & \multirow{2}{*}{\multicolumn{2}{|c|}{ TOTAL }} & \multirow{3}{*}{$\rho$} & \multirow{3}{*}{$\begin{array}{c}\text { OR } \\
(95 \% \text { CI })\end{array}$} \\
\hline & \multicolumn{2}{|c|}{ Puas } & \multicolumn{2}{|c|}{ Tidak Puas } & & & & \\
\hline & $\mathrm{N}$ & $\%$ & $\mathrm{~N}$ & $\%$ & $\mathrm{n}$ & $\%$ & & \\
\hline Handal & 24 & 60,0 & 16 & 40,0 & 40 & 100 & \multirow{3}{*}{0,034} & \multirow{3}{*}{$\begin{array}{c}2,64 \\
(1,15-6,0)\end{array}$} \\
\hline Kurang Handal & 21 & 36,2 & 37 & 63,8 & 58 & 100 & & \\
\hline TOTAL & 45 & 45,9 & 53 & 54,1 & 98 & 100 & & \\
\hline
\end{tabular}

Berdasarkan tabel diatas, diketahui dari 40 responden yang menyatakan pelayanan petugas loket pendaftaran handal, seperti pelayanan tepat waktu, teliti, penjelasan lengkap dan cara komunikasi petugas sangat baik, sebagian besar $60,0 \%$ responden merasa puas dengan pelayanan petugas, tetapi ada $40 \%$ yang tidak puas walaupun pelayanan petugas sudah handal. Hal ini disebabkan oleh faktor lain seperti petugas tidak tanggap, kuesioner yang dibuat kurang lengkap sehingga belum mengambarkan kepuasan pasien.Sedangkan dari 58 responden yang menyatakan pelayanan petugas loket pendaftarankurang handaldalam hal ketelitian, ketepatan waktu, cara berkomunikasi tidak baik dan penjelasan berbelit-belit sebagian besar. 63,8\% responden tidak puas dengan pelayanan petugas.Tetapi ada $36,2 \%$ yang merasa puas walaupun pelayanan petugas kurang handal. Hal ini dapat disebabkan oleh faktor lain seperti petugas loket baik dalam hal daya tanggap.Hasil analisis Chi-Square diperoleh nilai $\boldsymbol{\rho}=0,034<0.05$, maka secara statistik Ho ditolak dan Ha diterima, artinya terdapat hubungan antara kehandalan pelayanan petugas loket pendaftaran dengan tingkat kepuasan pasien. Analisis hubungan 2 variabel menunjukan nilai OR 2,64 artinya kurang handalnya pelayanan petugas loket pendaftaran RSUD Kepahiang mempunyai peluang 2,64 kali untuk memberikan ketidak puasan kepada pasien 


\section{2) Hubungan daya tanggap petugas loket pendaftaran dengan Kepuasan pasien rawat jalan RSUD Kepahiang}

Tabel 5

Hubungan daya tanggap petugas loket pendaftaran dengan Kepuasan pasien rawat jalan RSUD Kepahiang dengan Kepuasan pasien rawat jalan RSUD Kepahiang

\begin{tabular}{|c|c|c|c|c|c|c|c|c|}
\hline \multirow{3}{*}{$\begin{array}{c}\text { Daya } \\
\text { Tanggap }\end{array}$} & \multicolumn{4}{|c|}{ Tingkat Kepuasan } & \multirow{2}{*}{\multicolumn{2}{|c|}{ TOTAL }} & \multirow{3}{*}{$\rho$} & \multirow{3}{*}{$\begin{array}{c}\text { OR } \\
(95 \% \text { CI })\end{array}$} \\
\hline & \multicolumn{2}{|c|}{ Puas } & \multicolumn{2}{|c|}{ Tidak Puas } & & & & \\
\hline & $\mathrm{N}$ & $\%$ & $\mathrm{~N}$ & $\%$ & $\mathrm{~N}$ & $\%$ & & \\
\hline Baik & 25 & 61,0 & 16 & 39,0 & 41 & 100 & \multirow{3}{*}{0,020} & \multirow{3}{*}{$\begin{array}{c}2,89 \\
(1,26-6,6)\end{array}$} \\
\hline Kurang & 20 & 35,1 & 37 & 64,9 & 57 & 100 & & \\
\hline TOTAL & 45 & 45,9 & 53 & 54,1 & 98 & 100 & & \\
\hline
\end{tabular}

Berdasarkan tabel diatas, diketahui dari 41 responden yang menyatakan daya tanggap petugas loket pendaftaranbaik seperti petugas melengkapi syarat-syarat pendaftaran, tanggap dengan keluhan pasien, memberikan solusi yang tepat terhadap kesulitan pasien dan menawarkan bantuan terhadap kesulitan pasien, sebagian besar $61,0 \%$ reponden merasa puas dengan pelayanan petugas. Tetapi ada 39\% yang tidak puas walaupun daya tangap petugas sudah baik. Hal ini bisa disebabkan oleh faktor lain seperti petugas tidak memberikan jawaban secara jujur pada kuesioner, Sedangkan dari 57 responden yang menyatakan pelayanan petugas loket pendaftaran kurang baik, dari segi melengkapi syaratsyarat pendaftaran, tidak tanggap dengan keluhan pasien, tidak memberikan solusi yang tepat terhadap kesulitan pasien dan tidak menawarkan bantuan terhadap kesulitan pasien, sebagian besar $64,9 \%$ responden merasa tidak puas dengan pelayanan petugas. Tetapi ada $35,1 \%$ yang merasa puas walaupun daya tanggap petugas kurang baik. Hal ini dapat disebabkan oleh faktor lain salahsatunya yaitu petugas lebih handal walaupun tidak tanggap. Hasil analisis Chi-Square diperoleh nilai $\boldsymbol{\rho}=0,020<0.05$, maka secara statistik Ho ditolak dan Ha diterima, artinya terdapat hubungan antara daya tanggap pelayanan petugas loket pendaftaran dengan tingkat kepuasan pasien. Analisis hubungan 2 variabel menunjukan nilai OR2,89 artinya kurangnya daya tanggappelayanan petugas loket pendaftaran RSUD Kepahiang mempunyai peluang 2,89 kali untuk memberikan ketidakpuasan kepada pasien.

3) Kepuasan Pasien Rawat Jalan

Hasil analisis univariat menunjukkan bahwa sebagian besar responden yaitu 53 orang $(54,1 \%)$ menyatakan tidak puas. Responden merasa waktu buka loket pendaftaran terlambat, proses pendaftaran membutuhkan waktu yang panjang (kurang dari 5 Menit), pencarian/pengambilan rekam medik tidak cepat dan, petugas memberi informasi yang kurang dimengerti dan tidak lengkap tentang prosedur pendaftaran, cara bicara petugas loket kurang dipahami dan dimengerti, petugas loket kurang sopan, kurang ramah dan tidak tanggap, bicara ketus serta tidak mendengar keluhan pasien. 
Kepuasan pasien merupakan tolak ukur penting dari suatu produk layanan Rumah Sakit yang memberikan gambaran langsung atas tindakan-tindakan yang telah dilakukan oleh petugas Rumah Sakit.

\section{4) Kehandalan Petugas Loket Pendaftaran}

\begin{tabular}{lrr}
\multicolumn{1}{c}{ Hasil analisis } & univariat \\
menunjukkan bahwa & sebagian \\
besar responden yaitu & $(59,2 \%)$ \\
menyatakan petugas & loket \\
pendaftaran RSUD & Kepahiang
\end{tabular} kurang handal. Dalam penelitian ini petugas loket pendaftaran kurang handal. Menurut responden petugas kurang teliti, tidak tepat waktu, cara berkomunikasi tidak baik dan penjelasan berbelit-belit sehinga banyak responden yang merasa petugas kurang handal dan ini akan mempengaruhi tingkat kepuasan pasien di RSUD Kepahiang.

\section{Kehandalan (Reliability),} mencakup dua hal pokok, yaitu konsistensi kerja (performance) dan kemampuan untuk dipercaya (dependability). Hal ini berarti organisasi jasa kesehatan memberikan jasanya secara terpat semenjak saat pertama (right the first time). Selain itu juga memenuhi janjinya, misalnya menyampaikan jasanya sesuai dengan jadwal yang disepakati.

\section{5) Daya Tanggap Petugas Loket Pendaftaran}

$\begin{array}{cc}\text { Hasil analisis univariat } \\ \text { menunjukkan bahwa } & \text { sebagian } \\ \text { besar responden yaitu } & (58,2 \%) \\ \text { menyatakan daya tanggap } & \text { petugas } \\ \text { loket pendaftaran } & \text { RSUD }\end{array}$ Kepahiang kurang baik. Dalam penelitian ini daya tanggap petugas loket pendaftaran kurang baik, menurut responden petugas tidak memiliki kelengkapan syarat-syarat pendaftaran yang bisa dibaca secara umum, petugas tidak tanggap dengan keluhan pasien, tidak memberikan solusi yang tepat terhadap kesulitan pasien dan tidak menawarkan bantuan ketika pesien dalam kesulitan pada saat ingin mendaftar di loket pendaftaran. Sehinga banyak responden yang merasa daya tanggap petugas kurang baik dan ini akan mempengaruhi tingkat kepuasan pasien di RSUD Kepahiang.

Responsiveness, yaitu kemauan atau kesiapan para karayawan untuk memberikan jasa yang dibutuhkan pelanggan. Dalam hal ini daya tanggap petugas loket pendaftaran dalam merespon setiap persoalan yang dialami oleh pasien rawat jalan RSUD Kepahiang.

6) Hubungan kehandalan petugas loket pendaftaran dengan tingkat kepuasan pasien

Hasil penelitian menunjukkan bahwa terdapat hubungan antara kehandalan petugas loket pendaftaran dengan tingkat kepuasan pasien $(\mathrm{p}<0,05)$.

Indikator kehandalan yang dilakukan dalam penelitian ini merupakan suatu kesatuan yang terdiri dari kemampuan petugas loket untuk memberikan pelayanan teliti dan tepat waktu, membantu jika ada permasalahan pasien, menjelaskan secara lengkap, prosedur pendaftaran, memberikan informasi kepada pasien sebelum pelayanan diberikan, bersedia menanggapi keluhan pasien, petugas loket bersifat ramah, cara bicara sopan dan santun, cara komunikasi petugas loket sangat baik dan mudah dipahami, memberikan jawaban yang singkat dan tepat ketika anda bertanya mengenai pendaftaran, petugas loket memiliki integritas yang tinggi dan fasilitas di ruang tunggu sangat nyaman dan aman 
Menurut peneliti kehandalan petugas kesehatan dalam menyediakan mutu pelayanan yang memuaskan sangat didukung oleh sarana yang tersedia. Loket pendaftaran RSUD Kepahiang sendiri belum memiliki sarana yang cukup. Berdasarkan teori Dimensi ini menunjukkan kemampuan rumah sakit dalam memberikan pelayanan yang akurat, handal, dapat dipercaya, bertanggung jawab terhadap apa yang dijanjikan, tidak pernah memberikan janji yang berlebihan dan selalu memenuhi janjinya.

7) Hubungan daya tanggap petugas loket pendaftaran dengan tingkat kepuasan pasien

Hasil penelitian menunjukkan bahwa terdapat hubungan antara daya tanggap petugas loket pendaftaran dengan tingkat kepuasan pasien $(\mathrm{p}<0,05)$.

Indikator daya tanggap yang menjadi bahasan dalam penelitian ini mencakup petugas loket senyum dan menegur anda ketika sampai di ruang loket, petugas loket membantu anda menjelaskan tentang syarat-syarat pendaftaran yang harus anda siapkan, petugas loket tanggap melayani pasien, menerima dan melayani dengan baik, melakukan tindakan secara cepat dan tepat, melakukan tindakan sesuai prosedur, bersedia menanggapi keluhan pasien, tanggap terhadap kesulitan pasien yang terjadi tiba-tiba dan memberikan solusi yang tepat, menawarkan bantuan kepada anda ketika mengalami kesulitan walau tanpa diminta dan membantu anda memberikan informasi kunjungan rawat jalan berikutnya.

Hasil pengisian kuesioner yang disebarkan oleh peneliti atas 10 pertanyaan menunjukkan bahwa perlakuan petugas loket pendaftaran belum dilaksanakan secara cepat. Sering kali petugas terlambat memberikan pelayanan, pasien menunggu di loket pendaftaran lebih dari 10 menit yang disebabkan oleh kurangnya tenaga serta pengambilan dokumen yang butuh waktu lama.

Menurut peneliti ketanggapan petugas loket pendaftaran sangat penting, mengingat waktu adalah hal yang sangat berharga sehingga hal ini juga harus diperhatikan. Apalagi dalam bidang kesehatan waktu adalah hal pokok dalam menyelamatkan pasien. Petugas kesehatan di loket pendaftaran RSUD Kepahiang sendiri sudah cukup baik dalam menjalankan dimensi ini. Berdasarkan teori, dimensi ketanggapan merefleksikan komitmen untuk memberikan pelayanan tepat pada waktunya, yang berkaitan dengan keinginan dan kesiapan petugas untuk melayani. Dimensi ini merefleksikan persiapan rumah sakit sebelum memberikan pelayanan.

Sebagian besar pengunjung RSUD Kepahiang mempunyai persepsi yang baik terhadap pelayanan loket pendaftaran walaupun pelayanannya belum memenuhi standar.Daya tanggap petugas loket pendaftaran belum mengedepankan kepuasan pasien dan belum menerapkan patient care (Derpkes RI, 2004).

\section{SIMPULAN DAN SARAN}

1. Terdapat hubungan yang bermakna antara kehandalan petugas loket pendaftaran dengan tingkat kepuasan pasien rawat jalan RSUD Kepahiang

2. Terdapat hubungan yang bermakna antara daya tanggap petugas loket pendaftaran dengan tingkat kepuasan pasien rawat jalan RSUD Kepahiang Saran 
Hasil penelitian ini disarankan dapat dijadikan bahan bacaan dan informasi yang berkaitan dengan pengembangan ilmu tentang mutu pelayanan di fasilitas pelayanan kesehatan.

\section{DAFTAR PUSTAKA}

1. Armstrong, Gary dan Philip Kotler. 1996. Principles of Marketing. 7th edition. Prentice Hall International Inc, New Jersey.

2. Sofyan Assauri. 2003. Manajemen Pemasaran Jasa, Jilid 1, Jakarta, PT. Gramedia Pustaka Utama.

3. Parasuraman, et al. 1998. Service quality : A multiple item scale for measuring consumer perception of service quality

4. Azwar,Azrul., 1994. Pengantar Administrasi Kesehatan, Edisi ketiga, Ciputat,. Tangerang : Binarupa Aksara 5. Blank, W.E. 1982. Handbook for Developing Competency-Based Training Programs. Englewood Cliffs, New Jersey : Prentice-Hall.

6. Kotler dan Keller, 2007. Manajemen Pemasaran, Edisi 12, Jilid 1, PT.Indeks,. Jakarta. Hardiansyah. 2011. Kualitas Pelayanan Publik. Yogyakarta: Gava Media.

7. Laksono Trisantoro, 2015; Good Governance dan Sistem Menjaga Mutu Pelayanan Kesehatan, Surabaya.

8.Pohan, 2013;Jaminan Mutu

Layanan Kesehatan: Dasar-

Dasar Pengertian dan

Penerapan. Jakarta: EGC.

9. Warly, 2013; Tingkat Kepuasan Pelayanan Pasien Rawat Jalan di Poliklinik Kebidanan Rumah Sakit Ibnu Sina; Makasar. 